\title{
Wasteful Spending in Health Care: A US and UK international comparison
}

Une étude comparative des dépenses inutiles dans la santé publique aux Etats-

Unis et au Royaume-Uni

\section{Max Holdsworth}

\section{(2) OpenEdition}

\section{Journals}

Electronic version

URL: http://journals.openedition.org/rfcb/4381

DOI: $10.4000 /$ rfcb.4381

ISSN: 2429-4373

Publisher

CRECIB - Centre de recherche et d'études en civilisation britannique

Electronic reference

Max Holdsworth, « Wasteful Spending in Health Care: A US and UK international comparison », Revue Française de Civilisation Britannique [Online], XXIV-3 | 2019, Online since 30 August 2019, connection on 04 September 2019. URL : http://journals.openedition.org/rfcb/4381 ; DOI : 10.4000/rfcb.4381

This text was automatically generated on 4 September 2019 .

\section{c) $(9 \ominus$}

Revue française de civilisation britannique est mis à disposition selon les termes de la licence Creative Commons Attribution - Pas d'Utilisation Commerciale - Pas de Modification 4.0 International. 


\section{Wasteful Spending in Health Care: A US and UK international comparison}

Une étude comparative des dépenses inutiles dans la santé publique aux Etats-

Unis et au Royaume-Uni

Max Holdsworth

\section{Introduction}

1 The United States and the United Kingdom approach health care very differently. The United States has a largely private health insurance system while the United Kingdom has a public single-payer system. Different histories and contrasting public values have set up the fundamental systems that each country has today. With the UK's National Health Service recent anniversary of 70 years, it is important to look at its costs and benefits and compare them to systems in other countries. This paper looks into the role of wasteful spending in health care and asks how pervasive it is within the systems of the United States and the United Kingdom. Wasteful spending is a problem because it carries a high opportunity cost, unnecessarily excluding some services in substitute for others. Throughout this analysis I consider that the United States has a private health system because, although public single-payers exist such as Medicare and Medicaid, the dominant insurance scheme is through the employer and non-group coverage. The United Kingdom has a public supported single-payer system which asserts bargaining power and heavier regulation than in the United States. With the resources and definitions I use to explain wasteful spending, I show that both countries' health systems have waste but the United States has more evident waste with respect to the UK.

In 2017 the OECD published a 300-page report to illustrate the prevalence of wasteful spending across OECD countries. ${ }^{1}$ This report considers wasteful expenditures those that bear high costs relative to their benefits. Although the word "wasteful" is used by the 
OECD, I also use the word "excessive" to express that certain procedures are used more often than medical evidence would recommend; such procedures are used in excess, and therefore constitute dollars wasted. "Low-value" care is also a term I use throughout the analysis to portray how value might be produced, even though the costs to benefits ratio may be exceedingly high. The OECD estimates that about one fifth of health spending across the OECD is wasted. ${ }^{2}$ Their report categorizes wasteful spending into three different types: wasteful clinical care, operational waste and governance-related waste. ${ }^{3} \mathrm{~A}$ related study, from 2012, by Berwick and Hackbarth, quantified wasteful spending in the US. ${ }^{4}$ Their classifications match up to that of the OECD and therefore I include their definitions to aid understanding.

\section{The Three Forms of Waste in Health Care}

3 The first form of wasteful spending is wasteful clinical care. Wasteful clinical care includes any spending on treatments that does not significantly improve outcomes. Such care was either unnecessary, low-value or the final outcome might have been worse than what another treatment plan would have offered. ${ }^{5}$ Partially, this problem could be the consequence of the patient or provider having an imperfect amount of information. Patients might have limited knowledge about their health condition and related interventions. In this case they may put too much trust in medicine and their provider's ability to cure them, without assuming personal responsibility. Without critically thinking patients who can evaluate their own care, the provider can, even unknowingly, take advantage. The provider might be incentivized towards defensive practices and a roundabout of tests, which will lead to excess. When it leads to low effective treatments that could have been substituted with more effective ones, this information asymmetry is wasteful.

4 A collaboration of health specialists identified interventions that are commonly used in excess. Such interventions include imaging for lower back pain, antibiotics for upper respiratory infection, induction of labor and others. ${ }^{6}$ The OECD report suggests that such excessive interventions can be partly attributed to defensive medicine. Financial incentives that reward fee-for-service may be a contributing factor for over diagnosis and treatment. ${ }^{7}$ Although this category has directly to do with the care a patient receives, not all waste does; some forms of inefficiency, as explained below, create conditions that raise prices and exclude people from seeking the care they need. A Gallup poll conducted over the phone to a random sample of American adults found that in 2014, 33 percent of Americans put off medical care in the past 12 months for reasons of high cost. ${ }^{8}$ This percentage indicates a system that struggles to contribute to what is best for the health of the financially-burdened individuals.

5 The second form of wasteful spending, operational waste as the OECD defines, are "situations where health care could be produced using fewer or cheaper resources". ${ }^{9}$ This category of spending deals with the functioning of the markets that provide and consume health care and services. Although this is considered a form of wasteful spending, it is unlike wasteful clinical spending because it assumes the patient receives the right amount of services. ${ }^{10}$ Competitive markets are expected to sell and purchase goods at a certain cost that is both reasonable and fair. Similar to the OECD, Berwick and Hackbarth address what they call "Pricing Failures" as one of their six forms of waste. They discuss such failures as the difference between prices in the true market and a "well-functioning" 
market. ${ }^{11}$ Even if this category produces the outcomes we desire, its prices might be higher than they should be. On a system-wide level, this prevents money being used for other purposes, and on the individual level, anyone without the means or assistance to pay these prices is inevitably harmed.

6 The OECD's third and final form of wasteful spending is called governance-related waste. Administration is needed to run any health care system, but this category includes spending that is not essential to the delivery of health care. ${ }^{12}$ Countries' health care systems differ vastly in their complexity, which contributes to understandable differences in administrative expenditure. For example, a single-payer system like the National Health Service has less administrative spending than the private insurance system in the United States..$^{13}$ The OECD reported that administrative spending in the US was 8.2 percent of its total health expenditure in 2014, while in the UK administration as a percentage of total health expenditure was only 2.4 percent. ${ }^{14}$ In addition to wasteful administrative spending, this category includes intentional waste generated through corruption, fraud and abuse. In any large public or private enterprise in which there is profit we see attempts to take advantage of loopholes and weaknesses in the system. As the OECD suggests, increased transparency and common standards of reporting could help to detect and decrease this form of waste..$^{15}$

7 The framework of wasteful spending presented by the OECD sets the stage for a critical analysis of any system of health care. Even though Berwick and Hackbarth concentrate on the United States, it is feasible to apply their framework to other countries. In the next section, I will use both resources heavily, along with others, to look comparatively at the United States and the United Kingdom.

\section{Clinical, Operational and Governance-related Waste in the United States and the United Kingdom}

The United States devotes almost double the percentage of their GDP to health care than the average of the OECD countries; in 2015 the US spent 16.8 percent of their GDP on health versus the 9 percent average for OECD countries. ${ }^{16}$ Even with this expenditure, however, health outcomes in the US fall behind many individual countries and the average OECD rates, such as life expectancy at birth and the infant mortality rate. ${ }^{17}$ International comparison by The Commonwealth Fund offers comparison between the US and the UK, which again reveals higher American spending with worse outcomes. ${ }^{18}$ This relationship points to a dissociation between higher spending and lower benefits in the United States' health care system. Although I concentrate on the effects of health care, it is not the only factor impacting our health outcomes. A model from the University of Wisconsin Population Health Institute shows that the influence of clinical care on our health outcomes bears only 20 percent of the total influence of all health factors; much more impactful factors include economic and social factors such as employment and education..$^{19}$ Even if a health system is well functioning, the health outcomes such as life expectancy can be determined in many other life style factors. Therefore, I should point out that while I give my attention to inefficient and high spending in health care, the objective to obtain a healthier population must be followed from a more dynamic policy structure that considers health through all of its contributory factors. 
In terms of clinical care, the United States' private system lends itself to a large amount of waste. Patients get admitted for conditions that are preventable, for example, and care can be fragmented when doctors and hospitals do not discuss consistent plans for their patients. Additionally, the threat of malpractice litigation creates defensive medicine and pay-for-service schemes reward the amount of services over the outcomes they produce. Berwick and Hackbarth estimate that across the entire US health care system in 2011 at least $\$ 285$ billion were wasted between failures of health care delivery, failures of care coordination and overtreatment. ${ }^{20}$

The OECD published data about the use of diagnostic tests across its member countries. In 2014, the rates of computed tomography (CT) exams ranged from 31.9 exams per 1,000 people in Finland to 254.7 exams per 1,000 people in the United States. The figures are normalized over 1,000 people to allow for comparison among countries with different population sizes. The OECD average for CT exams is 131.6 per 1,000 people, and the United Kingdom falls well below that average at 75.7 per 1,000 people. ${ }^{21}$ Although the data do not show a direct indication of wasteful testing across all exams, such great cross-country variation is one indication of excessive testing in the US particularly.

The next form of waste is known as operational waste and is considered to be a failure to procure the least costly goods and services to produce the same intended outcome. Berwick and Hackbarth estimate that pricing failures cost the US health care system at least $\$ 84$ billion in $2011 .^{22}$ Inflation measures the increase of the prices of goods and services, and for all products this is targeted by the US and the UK at 2.0 percent per year. ${ }^{23}$ Here I exemplify pricing failures through high inflation. Health cost inflation can indicate the stability of health care markets in the US and the UK. The Consumer Price Index (CPI) is a measure of the price of certain goods within a designated product or service basket. Chart 1 below displays the change in the CPI for both countries since 1990, including spending categories of all items and medical care/health prices alone. ${ }^{24}$

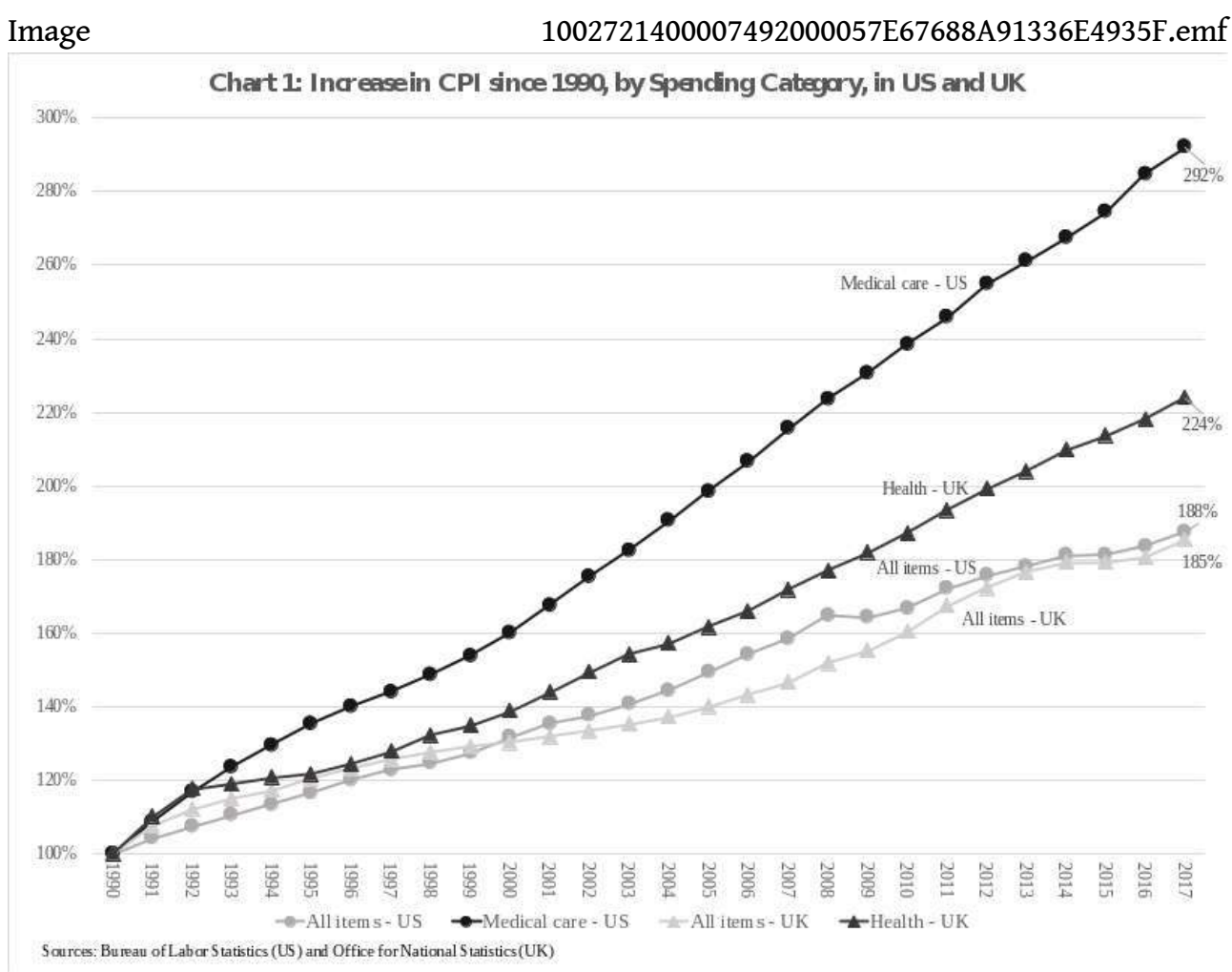



items in the US and the UK show that increases have been consistent. In 2017, the CPI for all items in the US was 188 percent of (or 1.88 times) its value in 1990, and in the UK was 185 percent. On average, this was an increase of about 3.2 percent per year, the same for both countries. However, the CPI for health goods and services (defined as "Medical Care" in the US and "Health" in the UK) both show that health related prices are increasing at a relatively faster rate. In the US, the "Medical Care" CPI was 292 percent higher than it was in 1990, and in the UK the "Health" CPI was 224 percent higher than in 1990. The US had, on average, a 7.1 percent increase per year in the health CPI, and the UK had a 4.6 percent increase per year. Consistently, both countries have a higher inflation rate in health-related prices than for all products, but the difference between the two CPI's is greater in the US.

These relationships show instability in the health market. While prices are the product of many factors, the steeper rise of the health CPI points to a more volatile market in the US. For the majority of the United States' health care system prices are unregulated by the government. This lack of control subjects the prices of medical care and pharmaceuticals to market forces of supply and demand. ${ }^{25}$ On the other hand, as a single-payer of health services the NHS is guided by a budget (from 2009/10 to 2016/17 the NHS budget increased on average by 1.3 percent per year ${ }^{26}$ ) that offers constraints and necessitates bargaining to hold down prices.

inerican health care system was written about by Anderson et al. in their article titled "It's the Prices, Stupid: Why the United States is so Different from Other Countries". ${ }^{27}$ In the paper they consider the relatively higher input prices of health care in the United States. They attribute this to higher physician salaries, more resource-intensive inpatient care and greater inefficiency. ${ }^{28}$ Their review of studies on health care payments and their benefits results in a similar conclusion seen in Chart 1 . They claim that prices are the essential drivers for the overall expenditures of countries. ${ }^{29}$ The United States, as Chart 1 shows, has a high inflation in health prices, which directly but not independently, contributes to high spending. High prices come with high opportunity costs; if great sums of money are used for some treatments, other treatments must be sacrificed. If high value is not derived from those expensive treatments, money is unnecessarily diverted from other uses, representing a market failure.

On a larger scale, there are expenditures involved in operating and renovating health care facilities that may not be made at the lowest cost. Throughout the UK the public finance initiative (PFI) is a scheme to initiate public projects through private sector finance and ownership. For the NHS in England, according to Appleby from Nuffield Trust, there were 127 schemes of PFI contracts between the NHS, social care and the private sector in 2016; the value of those deals was nearly $£ 13$ billion. ${ }^{30}$ The wasteful aspect of PFI's is that they cost more because of their involvement with the private sector. An article from 1999 showed that the contracts for hospitals in England under the public finance initiative cost 18 to 60 percent more than their construction costs. ${ }^{31}$ Although the private firms have a responsibility to the public authority that contracts them, they also have accountability to their shareholders. Therefore, the private lender expects a profit, and as the article shows, those lenders could gain real returns of 15 to 25 percent per year. ${ }^{32}$ Today the costs associated with the procurement of private finance are still apparent. According to a report in 2018 from the National Audit Office, PFI deals entered

Revue Française de Civilisation Britannique, XXIV-3 | 2019 
since 2013 were forecasted to give a return to investors of 2 to 4 percent above government borrowing. ${ }^{33}$

The PFI schemes help complete projects with a lack of public capital available to the NHS. Borrowing to construct hospitals and health service centers, which would have been traditionally a government responsibility in a nationalized NHS, now relies largely on contracts with private companies. ${ }^{34}$ In addition, the failure of these public finance initiatives is a possibility. For example, the recent liquidation of Carillion plc, which provided services to fourteen NHS trusts, including the building of two new hospitals, ${ }^{35}$ shows that financial risk is not avoided through PFI's. Higher private borrowing rates, costs and risks incurred by PFI's show that the NHS is not investing its resources at the lowest cost and rates available: designating it as a form of operational waste.

In terms of the third grouping of wasteful spending, governance-related waste, the United States and the United Kingdom differ. The independent review of wasteful spending conducted by Berwick and Hackbarth on the United States found that combined administrative complexity and fraud and abuse cost at least $\$ 189$ billion in 2011. ${ }^{36}$ Although there are no such estimates of governance-related waste in the UK, common measures can help to describe the differences. The OECD report includes data on administrative spending across the member countries. The United States again comes out with the highest value: administrative spending in the US was 8.2 percent of its total health expenditure in 2014. However, the UK spent less on administration as a percent of total health expenditure than the OECD average (2.4 percent in the UK, and 3.2 percent average for all OECD countries ${ }^{37}$ ). The entire administrative spending of the US, although high, may not necessarily be wasteful. The US has a very complex health care system and therefore requires more administration. The comparative administrative spending may indicate that the US wastes money on administration, but it might simply show the natural costs of its fragmented care system. Estimates by Berwick and Harkbarth show us that non-negligible amounts of money are wasted through administrative complexity in the US: at least $\$ 107$ billion in waste in 2011..$^{38}$

Figures on combined management and administrative spending in the NHS help compare these costs. In a report by the Health Committee of the House of Commons in 2010, a figure shows the cost of management in the NHS between 1996 and 2009. During that period, the management costs of the NHS as a percent of the NHS budget actually fell from 5.1 percent in 1996-1997 to 3.0 percent in 2008-2009. ${ }^{39}$ Similar updated figures are more difficult to find. An undated estimate from The King's Fund that combines spending on administrative and management says that about $£ 8$ billion of the $£ 100$ billion NHS budget is spent on management and administration..$^{40}$ Another report from The King's Fund shows that the number of NHS managers fell by 18.8 percent from 2010 to 2017, while staff numbers in other functional groups, such as nurses and ambulance staff, increased ${ }^{41}$ On the other hand, according to NHS Digital, the mean annual earnings of senior managers in NHS Trusts and Clinical Commissioning Groups (CCG's) in England was $£ 77,435$ in the 12-month period ending in September 2018, 2.2 percent higher the amount one year before. ${ }^{42}$ As with the United States, it is hard to designate such high salaries and spending in the NHS as wasteful. Health care systems serve a large amount of people constantly, and it would be simplistic to think that less administrative and management spending, without other structural changes, could lead to a more efficient system. In both countries, a more in depth cost-benefit analysis of spending on administration and management should be conducted to target its wastefulness. 


\section{Alternatives} the National Institute for Health and Care Excellence (NICE), provides independent evidence-based guidance to policy makers and health care providers in England. NICE works to rigorously review new medicines, technologies and diagnostics. Their reviews assess new treatments on both their clinical- and cost-effectiveness. ${ }^{45}$ Amanda Andler, a consultant physician in England, summarizes that NICE "helps the NHS allocate resources to maximise health for the greatest number of people". ${ }^{46}$ The NICE charter describes the methodological framework of their reviews, which include calculating Quality Adjusted Life Years (QALYs) that can be gained by new treatments in relation to the current treatment. ${ }^{47}$ Since NICE advises NHS England, their academic review process helps maintain the low-cost and effectiveness of covered treatment. The method of NICE's approval also ensures that producers and providers choose high-value health care services.

High costs can also be addressed more formally in the UK. In March 2014, the Procurement, Investment \& Commercial Division of the NHS published a report titled "Combating Inflation - Guidance". The report advised NHS providers, specifically those in the procurement of services, to "resist blanket inflationary price increases from suppliers". ${ }^{48}$ The report explained that NHS budgets at that time were not increasing, and therefore higher input prices would not be supported. This guidance exemplifies that resisting inflation can have great cost savings for the NHS; for example, Central 
Manchester University Hospitals NHS Foundation Trust (CMFT) avoided over £2 million in inflationary increases through such negotiations with suppliers. ${ }^{49}$

Advice like this, outside of the public providers of health care, such as Medicare and Medicaid, is unlikely to be public in the United States and might only occur on a small scale. The NHS document demonstrates the value of bargaining power throughout an entire country. A single-payer system like the NHS is able to conduct price negotiations that a private system like the United States' cannot. The effects of such price negotiations can be seen in the CPI, where the UK's health inflation is much lower than that of the US. The strength of the UK's market to manage prices demonstrates too its ability to keep wasteful operational spending down. Their price negotiations do not appear to be related to lower quality compared to the US either, as shown by The Commonwealth Fund: their report from 2014 ranked the UK the first in quality care among eleven countries, including the US, which came in fifth. Similarly, another ranking, by the World Health Organization, ranked the United Kingdom's health care system as higher than the United States in terms of overall health system performance (18th for the UK and 37th for the US)..$^{50}$

\section{Conclusion}

The United Kingdom avoids a lot of sources of wasteful spending that the United States faces. The United States tends to use excessive testing and clinical care, has high health costs and has significantly larger rates of administrative spending. Under Affordable Care Act provisions, including the integration of accountable care organizations, and current policy attempts to stabilize pharmaceutical prices, ${ }^{51}$ the United States is attempting to reduce its inefficiency. Under the Medicare single-payer program, which regulates its health providers, research has shown that a reduction in payments has kept down health care inflation. ${ }^{52}$ The UK increasingly recognizes that previous legislation has brought lesscoordination caused by fragmented care. For this reason, NHS England is embracing integrated care systems similar to ACO's. ${ }^{53}$ In terms of administrative spending, the UK's Department of Health committed in 2010 to a reduction of administrative spending in the NHS and reinvestment of those funds to service delivery. ${ }^{54}$ Worldwide, too, there is an awareness that low-value spending affects our health care systems. The physician-led campaign to address wasteful clinical spending "Choosing Wisely" was started in the United States and now has expanded to both England and Wales. ${ }^{55}$

Although the United States and the UK are working to decrease wasteful spending, more work needs to be done. The United States needs to address its high prices in relation to the rest of the world, particularly because it harms people that are increasingly unable to afford the insurance or the care they need. The UK's NHS, as it moves into the future from its 70th year anniversary, needs to support accountable care and integrated budgets to maximize the population health benefit given a limited NHS budget. It is important that both countries put greater monitoring on forms of wasteful spending, and important too is the acceptance of Choosing Wisely recommendations to reduce certain practices that physicians claim do not produce sufficient benefits. In a time when prices continue to rise, the population continues to age and chronic diseases threaten to keep us sicker for longer, it is essential that health care systems address wasteful spending and strive to produce the equitable and efficient care that people deserve. 
Max Holdsworth is a recent graduate from the Master of Arts program in Urban Affairs and Public Policy at the University of Delaware, in Newark, Delaware, USA. His research interests are in data-driven public health interventions. During Max's undergraduate and graduate degrees, he followed closely the trends in the health sector of both his home and paternal countries of the United States and the United Kingdom.

\section{BIBLIOGRAPHY}

Anderson, Gerard F., Reinhardt, Uwe E., Hussey, Peter S. and Petrosyan, Varduhi "It's the Prices, Stupid: Why the United States is so Different from Other Countries", Health Affairs 22 (2003).

Andler, Amanda, "What Works? what's Good Value for Money? the Role of NICE for the NHS", The Endocrinologist 127 (2018).

Appleby, John, Making sense of PFI, 6 October 2017, https://www.nuffieldtrust.org.uk/resource/ making-sense-of-pfi, consulted 29 January 2019.

Bank of England, Inflation and the 2\% target, 22 January 2019, https://www.bankofengland.co.uk/ monetary-policy/inflation, consulted 29 January 2019.

Berwick, Donald M. and Hackbarth, Andrew D., "Eliminating Waste in US Health Care”, Jama 307, no. 14 (2012), pp. 1513-1516.

Board of Governors of the Federal Reserve System, Why does the Federal Reserve Aim for 2 Percent Inflation Over Time, 26 January 2015, https://www.federalreserve.gov/faqs/economy_14400.htm, consulted 29 January 2019.

Bureau of Labor Statistics, CUUR0000SAO (all Items); CPI-all Urban Consumers (Current Series), https:// data.bls.gov/cgi-bin/surveymost?cu, consulted 29 January 2019.

Bureau of Labor Statistics, CUUR0000SAM (Medical Care); CPI-all Urban Consumers (Current Series), https://data.bls.gov/cgi-bin/surveymost?cu, consulted 29 January 2019.

Chalkidou, Kalipso and Appleby, John, "Eliminating Waste in Healthcare Spending", British Medical Journal [Bmj] 356 (2017).

Clemens, Jeffrey, Gottlieb, Joshua D. and Shapiro, Adam Hale, Medicare Payment Cuts Continue to Restrain Inflation, 9 May 2016, https://www.frbsf.org/economic-research/publications/economicletter/2016/may/medicare-payment-cuts-affect-core-inflation/, consulted 29 January 2019.

Davis, Karen, Stremikis, Kristof, Squires, David and Schoen, Cathy, Mirror, Mirror on the Wall, 2014 Update: How the U.S. Health Care System Compares Internationally, 16 June 2014, https:// www.commonwealthfund.org/publications/fund-reports/2014/jun/mirror-mirror-wall-2014update-how-us-health-care-system, consulted 29 January 2019.

Department of Health, Department of Health - Spending Review 2010, 20 October 2010, https:// webarchive.nationalarchives.gov.uk/+/http://www.dh.gov.uk/en/MediaCentre/Pressreleases/ DH_120676, consulted 29 January 2019. 
The Economist, Why Trump's Plan Will Not Cut Drug Prices, 19 May 2018, https:// www.economist.com/leaders/2018/05/19/why-trumps-plan-will-not-cut-drug-prices, consulted 29 January 2019.

Finance \& NHS Directorate, Procurement, Investment \& Commercial Division (PICD), Combating Inflation - Guidance, March 2014, https://www.gov.uk/government/publications/nhs-resistingcost-inflation-pressures, consulted 29 January 2019.

Gaffney, Declan, Pollock, Allyson M., Price, David and Shaoul, Jean, "NHS capital expenditure and the private finance initiative-expansion or contraction?”, BMJ 319, no. 7201 (1999), pp. 48-51.

Gaffney, Declan, Pollock, Allyson M., Price, David and Shaoul, Jean, "PFI in the NHS-is there an economic case?", BMJ 319 (1999), pp. 116-119.

Ham, Chris, Making Sense of Integrated Care Systems, Integrated Care Partnerships and Accountable Care Organisations in the NHS in England, 10 February 2018, https://www.kingsfund.org.uk/ publications/making-sense-integrated-care-systems, consulted 29 January 2019.

The House of Commons: Health Committee, Public Expenditure on Health and Personal Social Services 2009, (London: The Stationery Office Limited, 2010).

Hurley, Richard, “Can Doctors Reduce Harmful Medical Overuse Worldwide?”, BMJ : British Medical Journal 349 (2014).

Kaiser Family Foundation, Summary of the Affordable Care Act, 23 April 2013, http://files.kff.org/ attachment/fact-sheet-summary-of-the-affordable-care-act, consulted 29 January 2019.

The King's Fund, The NHS Budget and how it has Changed, 02 May 2017, https:// www.kingsfund.org.uk/projects/nhs-in-a-nutshell/nhs-budget, consulted 29 January 2019.

The King's Fund, Myth four: the NHS has too many managers, https://www.kingsfund.org.uk/ projects/health-and-social-care-bill/mythbusters/nhs-managers, consulted 29 January 2019.

The King's Fund, NHS staffing numbers, 20 May 2017, https://www.kingsfund.org.uk/projects/nhsin-a-nutshell/nhs-staffing-numbers, consulted 29 January 2019.

Levinson, Wendy, "Choosing Wisely Around the World: Professionalism as a Force to Reduce Unnecessary Care", BMJ Opinion 2017.

National Audit Office, PFI and PF2, (London: National Audit Office, 2018).

National Institute for Health and Care Excellence (NICE), NICE Charter 2018, https:// www.nice.org.uk/Media/Default/About/Who-we-are/NICE_Charter.pdf, consulted 29 January 2019.

NHS Digital, NHS Staff Earnings Estimates - September 2018, Provisional Statistics, 20 December 2018, https://digital.nhs.uk/data-and-information/publications/statistical/nhs-staff-earningsestimates/september-2018-provisional-statistics, consulted 29 January 2019.

NHS Improvement, Update on Carillion liquidation, 15 January 2018, https://improvement.nhs.uk/ news-alerts/update-carillion-liquidation/, consulted 29 January 2019.

OECD, Tackling Wasteful Spending on Health, (Paris, OECD Publishing, 2017).

OECD, Tackling Wasteful Spending on Health: Highlights, (Paris, OECD Publishing, 2017), http:// www.oecd.org/els/health-systems/Tackling-Wasteful-Spending-on-Health-Highlightsrevised.pdf, consulted 29 January 2019.

Office for National Statistics, Cpi Index 00: All Items 2015=100, https://www.ons.gov.uk/, consulted 29 January 2019. 
Office for National Statistics, Cpi Index 06: Health 2015=100, https://www.ons.gov.uk/, consulted 29 January 2019.

Riffkin, Rebecca, Cost Still a Barrier Between Americans and Medical Care, 28 November 2014, https:// news.gallup.com/poll/179774/cost-barrier-americans-medical-care.aspx, consulted 29 January 2019.

University of Wisconsin Population Health Institute, What and Why We Rank: County Health Rankings Model, 2018, http://www.countyhealthrankings.org/explore-health-rankings/what-andwhy-we-rank, consulted 29 January 2019.

The World Factbook, Country Comparison :: Infant Mortality Rate, https://www.cia.gov/LIBRARY/ publications/the-world-factbook/fields/354rank.html, consulted 29 January 2019.

The World Factbook, Country Comparison ::Life Expectancy at Birth, https://www.cia.gov/library/ publications/resources/the-world-factbook/fields/355rank.html, consulted 29 January 2019.

World Health Organization, Global Health Expenditure Database, 25 January 2019, http:// apps.who.int/nha/database/, consulted 29 January 2019.

World Health Organization, The World Health Report 2000, (Geneva, World Health Organization, 2000).

\section{NOTES}

1. OECD, Tackling Wasteful Spending on Health, (Paris, OECD Publishing, 2017).

2. Kalipso Chalkidou and John Appleby, "Eliminating Waste in Healthcare Spending", British Medical Journal [Bmj] 356 (2017), p. j570 and OECD, Tackling Wasteful Spending on Health, (Paris, OECD Publishing, 2017).

3. OECD, Tackling Wasteful Spending on Health, (Paris, OECD Publishing, 2017), p. 61.

4. Donald M. Berwick and Andrew D. Hackbarth, "Eliminating Waste in US Health Care", Jama 307, no. 14 (2012), pp. 1513-1516.

5. OECD, Tackling Wasteful Spending on Health, (Paris, OECD Publishing, 2017), pp. 61-64.

6. Richard Hurley, "Can Doctors Reduce Harmful Medical Overuse Worldwide?", BMJ : British Medical Journal 349 (2014), p. g4289.

7. OECD, Tackling Wasteful Spending on Health, (Paris, OECD Publishing, 2017), p. 73.

8. Rebecca Riffkin, Cost Still a Barrier Between Americans and Medical Care, 28 November 2014, https://news.gallup.com/poll/179774/cost-barrier-americans-medical-care.aspx, consulted 29 January 2019.

9. OECD, Tackling Wasteful Spending on Health, (Paris, OECD Publishing, 2017), p. 159.

10. Ibid., p. 159.

11. Donald M. Berwick and Andrew D. Hackbarth, "Eliminating Waste in US Health Care", Jama 307, no. 14 (2012), pp. 1513-1516.

12. OECD, Tackling Wasteful Spending on Health, (Paris, OECD Publishing, 2017), p. 229.

13. OECD, Tackling Wasteful Spending on Health: Highlights, (Paris, OECD Publishing, 2017), http:// www.oecd.org/els/health-systems/Tackling-Wasteful-Spending-on-Health-Highlightsrevised.pdf, consulted 29 January 2019.

14. OECD, Tackling Wasteful Spending on Health, (Paris, OECD Publishing, 2017), p. 232.

15. Ibid., p. 232.

16. World Health Organization, Global Health Expenditure Database, 25 January 2019, http:// apps.who.int/nha/database/, consulted 29 January 2019. 
17. Reference made to data available from The World Factbook, Country Comparison :: Infant Mortality Rate, https://www.cia.gov/LIBRARY/publications/the-world-factbook/ fields/354rank.html, consulted 29 January 2019 and The World Factbook, Country Comparison ::Life Expectancy at Birth physician-led campaign "Choosingacesation to nity cost, whereas on the individual level nd the UK, which assert the high spend, https://www.cia.gov/library/publications/resources/theworld-factbook/fields/355rank.html, consulted 29 January 2019.

18. Reference made to Karen Davis, Kristof Stremikis, David Squires and Cathy Schoen, Mirror, Mirror on the Wall, 2014 Update: How the U.S. Health Care System Compares Internationally, 16 June 2014, https://www.commonwealthfund.org/..., consulted 29 January 2019.

19. University of Wisconsin Population Health Institute, What and Why We Rank: County Health Rankings Model, 2018, http://www.countyhealthrankings.org/explore-health-rankings/what-andwhy-we-rank, consulted 29 January 2019.

20. Donald M. Berwick and Andrew D. Hackbarth, "Eliminating Waste in US Health Care", Jama 307, no. 14 (2012), pp. 1513-1516.

21. OECD, Tackling Wasteful Spending on Health, (Paris, OECD Publishing, 2017), p. 74.

22. Donald M. Berwick and Andrew D. Hackbarth, "Eliminating Waste in US Health Care", Jama 307, no. 14 (2012), pp. 1513-1516.

23. Board of Governors of the Federal Reserve System, Why does the Federal Reserve Aim for 2 Percent Inflation Over Time, 26 January 2015, https://www.federalreserve.gov/faqs/ economy_14400.htm, consulted 29 January 2019 and Bank of England, Inflation and the 2\% target, 22 January 2019, https://www.bankofengland.co.uk/monetary-policy/inflation, consulted 29 January 2019.

24. Data sources for the US: Bureau of Labor Statistics, CUUR0000SAO (all Items); CPI-all Urban Consumers (Current Series) and CUUR0000SAM (Medical Care); CPI-all Urban Consumers (Current Series), https://data.bls.gov/cgi-bin/surveymost?cu, consulted 29 January 2019; data sources for the UK: Office for National Statistics, Cpi Index 00: All Items 2015=100 and Cpi Index 06: Health 2015=100, https://www.ons.gov.uk/, consulted 29 January 2019.

25. Reference made to The Economist, Why Trump's Plan Will Not Cut Drug Prices, 19 May 2018, https://www.economist.com/leaders/2018/05/19/why-trumps-plan-will-not-cut-drug-prices, consulted 29 January 2019.

26. Reference made to data available from The King's Fund, The NHS Budget and how it has Changed, 02 May 2017, https://www.kingsfund.org.uk/projects/nhs-in-a-nutshell/nhs-budget, consulted 29 January 2019.

27. Gerard F. Anderson, Uwe E. Reinhardt, Peter S. Hussey and Varduhi Petrosyan, "It's the Prices, Stupid: Why the United States is so Different from Other Countries", Health Affairs 22 (2003).

28. Ibid.

29. Gerard F. Anderson, Uwe E. Reinhardt, Peter S. Hussey and Varduhi Petrosyan, "It's the Prices, Stupid: Why the United States is so Different from Other Countries", Health Affairs 22 (2003).

30. John Appleby, Making sense of PFI, 6 October 2017, https://www.nuffieldtrust.org.uk/ resource/making-sense-of-pfi, consulted 29 January 2019.

31. Declan Gaffney, Allyson M. Pollock, David Price and Jean Shaoul, "PFI in the NHS-is there an economic case?", BMJ 319 (1999), pp. 116-119.

32. Ibid.

33. National Audit Office, PFI and PF2, (London: National Audit Office, 2018), p. 14.

34. Declan Gaffney, Allyson M. Pollock, David Price and Jean Shaoul, "NHS capital expenditure and the private finance initiative-expansion or contraction?", BMJ 319, no. 7201 (1999), pp. 48-51. 
35. NHS Improvement, Update on Carillion liquidation, 15 January 2018, https:// improvement.nhs.uk/news-alerts/update-carillion-liquidation/, consulted 29 January 2019.

36. Donald M. Berwick and Andrew D. Hackbarth, "Eliminating Waste in US Health Care", Jama 307, no. 14 (2012), pp. 1513-1516.

37. OECD, Tackling Wasteful Spending on Health, (Paris, OECD Publishing, 2017), p. 232.

38. Donald M. Berwick and Andrew D. Hackbarth, "Eliminating Waste in US Health Care", Jama 307, no. 14 (2012), pp. 1513-1516.

39. The House of Commons: Health Committee, Public Expenditure on Health and Personal Social Services 2009, (London: The Stationery Office Limited, 2010), p. Ev 179.

40. The King's Fund, Myth four: the NHS has too many managers, https://www.kingsfund.org.uk/ projects/health-and-social-care-bill/mythbusters/nhs-managers, consulted 29 January 2019.

41. The King's Fund, NHS staffing numbers, 20 May 2017, https://www.kingsfund.org.uk/projects/ nhs-in-a-nutshell/nhs-staffing-numbers, consulted 29 January 2019.

42. Reference made to data available from NHS Digital, NHS Staff Earnings Estimates - September 2018, Provisional Statistics, 20 December 2018, https://digital.nhs.uk/data-and-information/ publications/statistical/nhs-staff-earnings-estimates/september-2018-provisional-statistics, consulted 29 January 2019.

43. Kaiser Family Foundation, Summary of the Affordable Care Act, 23 April 2013, http:// files.kff.org/attachment/fact-sheet-summary-of-the-affordable-care-act, consulted 29 January 2019.

44. Kaiser Family Foundation, Summary of the Affordable Care Act, 23 April 2013, http:// files.kff.org/attachment/fact-sheet-summary-of-the-affordable-care-act, consulted 29 January 2019.

45. National Institute for Health and Care Excellence (NICE), NICE Charter 2018, https:// www.nice.org.uk/Media/Default/About/Who-we-are/NICE_Charter.pdf, consulted 29 January 2019.

46. Amanda Andler, "What Works? what's Good Value for Money? the Role of NICE for the NHS", The Endocrinologist 127 (2018).

47. National Institute for Health and Care Excellence (NICE), NICE Charter 2018, https:// www.nice.org.uk/Media/Default/About/Who-we-are/NICE_Charter.pdf, consulted 29 January 2019.

48. Finance \& NHS Directorate, Procurement, Investment \& Commercial Division (PICD), Combating Inflation - Guidance, March 2014, https://www.gov.uk/government/publications/nhsresisting-cost-inflation-pressures, consulted 29 January 2019 , p. 5.

49. Ibid., pp. 6-7.

50. World Health Organization, The World Health Report 2000, (Geneva, World Health Organization, 2000), p. 155.

51. Reference made to The Economist, Why Trump's Plan Will Not Cut Drug Prices, 19 May 2018, https://www.economist.com/leaders/2018/05/19/why-trumps-plan-will-not-cut-drug-prices, consulted 29 January 2019.

52. Jeffrey Clemens, Joshua D. Gottlieb and Adam Hale Shapiro, Medicare Payment Cuts Continue to Restrain Inflation, 9 May 2016, https://www.frbsf.org/economic-research/publications/economicletter/2016/may/medicare-payment-cuts-affect-core-inflation/, consulted 29 January 2019.

53. Chris Ham, Making Sense of Integrated Care Systems, Integrated Care Partnerships and Accountable Care Organisations in the NHS in England, 10 February 2018, https://www.kingsfund.org.uk/ publications/making-sense-integrated-care-systems, consulted 29 January 2019.

54. Reference made to Department of Health, Department of Health - Spending Review 2010, 20 October 2010, https://webarchive.nationalarchives.gov.uk/+/http://www.dh.gov.uk/en/ MediaCentre/Pressreleases/DH_120676, consulted 29 January 2019. 
55. Wendy Levinson, "Choosing Wisely Around the World: Professionalism as a Force to Reduce Unnecessary Care”, BMJ Opinion 2017.

\section{ABSTRACTS}

In health care, greater attention in the United States and the United Kingdom is being given to maximize the benefit of dollars and pounds spent. With the persistent increase in health care prices and demographic changes, evidence-based high-value care has become essential. This paper examines the nature of wasteful uses of health dollars. The United States wastes money in its unnecessarily high use of testing and procedures and through its volatile prices that affect how health services are managed. Administrative costs in the US are also high, due to its relatively unregulated system. This comparative analysis shows that the UK, on the other hand, spends less per-capita on health with verifiably better outcomes; nonetheless, the UK too has sources of low-value spending. More analysis of this problem could help to produce sound public policy, which would reduce waste and release resources for the improvement of services.

Dans le secteur de la santé, les États-Unis et le Royaume-Uni accordent une plus grande attention à l'optimisation des dépenses. Avec la hausse des prix et les changements démographiques, les soins de qualité fondés sur des recherches scientifiques sont devenus essentiels. Cet article examine la nature de l'utilisation inutile des dépenses consacrées à la santé. Les États-Unis gaspillent de l'argent en utilisant inutilement des tests et des procédures et en raison de la volatilité de leurs prix, qui influent sur la gestion des services de santé. Les coûts administratifs aux États-Unis sont également élevés en raison de son système relativement non réglementé. Cette analyse comparative montre que le Royaume-Uni, en revanche, dépense moins par habitant avec de bien meilleurs résultats. Malgré cela, le Royaume-Uni possède également des sources de dépenses à faible valeur ajoutée. Une analyse plus poussée de ce problème pourrait aider à élaborer une politique publique judicieuse, qui réduirait le gaspillage et dégagerait des ressources pour l'amélioration des services.

\section{INDEX}

Mots-clés: politique de santé, dépenses de santé, politique comparative, Etats-Unis Keywords: health care, low-value care, health spending, Choosing Wisely, comparative health policy

\section{AUTHOR}

\section{MAX HOLDSWORTH}

University of Delaware 